\title{
Is Transhumanism a New Face of Bioethics?
}

\author{
O transhumanismo é uma nova face da bioética?
}

GRZEGORZ HOŁUB ${ }^{\mathrm{a}}$

\begin{abstract}
The paper deals with a possible interdependence between bioethics and transhumanism. It seems that nowadays transhumanism is a separate discipline and we can say at most about bioethical aspects of that. However, a more in-depth investigation reveals that transhumanism is a rival of the contemporary bioethics and tends to take control over it. So, this paper tried to prove that this is not a necessity. There are still vital differences between bioethics and transhumanism and they justify keeping the former separate. The main difference concerns the object of investigation: bioethics is about ethical enquiry of the existing, bodily human being, whereas transhumanism is directed toward a future creature called posthuman. Thus, although there are attempts within transhumanism to replace bioethics, they are still two separate fields of investigation and hence the former is not a new and fully-fledged face of the latter.
\end{abstract}

Keywords: Bioethics. Transhumanism. Ethics. Posthuman being. Interdisciplinary approach.

\section{Resumo}

$\mathrm{O}$ artigo trata de uma possível interdependência entre bioética e transumanismo. Parece que hoje em dia o transhumanismo é uma disciplina separada e podemos dizer no máximo sobre aspectos bioéticos disso. No entanto, uma investigação mais aprofundada revela que 0 transhumanismo é um rival da bioética contemporânea e tende a assumir o controle sobre ela. Portanto, este artigo tentou provar que isso não é uma necessidade. Ainda existem diferenças vitais entre bioética e transhumanismo e elas justificam manter o primeiro em separado. A principal diferença diz respeito ao objeto de investigação: a bioética trata da investigação ética do ser humano corporal existente, enquanto o transhumanismo é direcionado a uma futura criatura chamada pós-humana. Assim, embora existam tentativas

a The Pontifical University of John Paul II, Cracow, Poland. Ph.D. in Philosophy, e-mail: grzegorz.holub@upjp2.edu.pl 
no transhumanismo de substituir a bioética, eles ainda são dois campos separados de investigação e, portanto, o primeiro não é uma face nova e completa do segundo.

Palavras-chave: Bioética. Transhumanismo. Ética. Ser pós-humano. Abordagem interdisciplinar.

\section{Introduction}

Nowadays transhumanism is a very popular and even fashionable trend in academic and public debates. Its main idea - entertained by adherents of this trend concerns such interventions in human life that it finally becomes more than human, meaning by that "better" than human life. Generally, the promotion of thinking in terms of "better" in contrast to "good" is typical of transhumanist deliberations. At the same time, these two concepts constitute essential stumbling blocks because of their imprecision and vagueness. Transhumanism as such draws on various sources and as a result it is not easy to establish its methodological status. Adherents of this trend usually point to progress and spectacular achievements of various sciences and technologies as genetics, genetic engineering, cell biology, information technology, and others as presuppositions and even starting points for such a more-than-human existence. But it is also obvious - especially after a critical examination - that transhumanism is densely saturated with non-scientific symbols and presuppositions (philosophical and even scientisitic), which is not equally acknowledged by its adherents.

When we look at personalities involved in transhumanism, we can see the figures of philosophers, writers and various kinds of thinkers and futurologists. What is surprising is that in this circle there are not so many scientists (i. e. representatives of hard sciences). Instead, there are a good number of people who are well known from bioethical debates worldwide. Based on this, we can put the question: is transhumanism a new stage of bioethical discussions? Maybe the contemporary bioethics is slowly absorbed by transhumanism and is reconfiguring itself within a transhumanist paradigm?

In this paper, I will be trying to analyse and finally answer this question although there is an initial suggestion that there are only bioethical dimensions of transhumanism. Thus, in the first part, I will accept fully the suggestion that bioethics is concerned with some selected issues of transhumanism and we will provide reasons for that. In the 
second part, however, I will challenge this suggestion pointing to a far more prominent and far-reaching role of transhumanism. Finally, I will be trying to establish what kind of ethics results from a possible fusion of bioethics and transhumanism and whether this fusion is inevitable.

\section{Bioethics as an aspect of Transhumanism}

When we look at specific ideas of transhumanism, we realize that not all of them have something to do with a contemporary paradigm of bioethics understood as a continuation and prolongation of medical ethics. This becomes evident when transhumanists express their view that biology is something, which restricts our development and expansion, and — as a result — it would be better to overcome it (see e.g. BOSTROM, 2005, p. 21); such a thesis is for a typical bioethicist perplexing and even alien. Bioethics assumes on the very fundamental level that we, human beings, are biological creatures (even if not only biological ones) ${ }^{1}$. The scenario of a gradual abandonment of biological existence would take place when particular organs of our body were replaced by artificial counterparts, which are more durable and perform given functions more efficiently. A model of cyborg shows what it means to be partially natural (biological) and partially artificial. For example, the implantation of artificial limbs, heart, kidneys, eyes, and even an artificial cortex would lead to a situation in which biology plays a lesser and lesser role in our lives. In extreme cases mentioned by radical transhumanists, the human being would be transferred to the artificial world altogether. Such a scenario is contemplated by Ray Kurzweil who advocates the so-called uploading of the person (KURZWEIL, 2005). The person who is not a biological creature anymore but akin to a computer program, is constantly upgraded and downloaded with new vessels (getting one artificial body after another). In the wish to be someone other than a human being associated with a biological body goes further. In the "Transhumanist Declaration (2012)" the whole earthly dwelling of the human being is perceived as a kind of limitation, which

\footnotetext{
${ }^{1}$ It is reflected in sciences in which bioethics as such is interested. They are centered on human biological constitution in the first place. And Daniel Callahan puts it clearly, "yet it is the medical and biological sciences in which bioethics found its initial impetus, and in which it has seen the most intense activity" (CALLAHAN, 2004, p. 279).
} 
should be overcome (2013, p. 54-55); thus, leaving the planet Earth will liberate us from a present confinement and offer us new possibilities for being-more-than-we-are right now.

Many of these postulates seem to have a science fiction character. Nevertheless, their implementation, if they are to take place at all, would be impossible without reaching a very advanced level of technical sciences. For example, to produce an artificial cortex able to provide better conditions for mental operations would require an imaginable level of theoretical and practical knowledge and skill concerning this important organ (right now unavailable). Of course, an implantation of such a manufactured cortex into a human body would be not only a matter of technical feasibility but also a matter of ethical permissibility. Hence, a bioethical apparatus will have to be applied here. Production of such a cortex with all its complexity would engage specialists who are far from medicine and medical sciences (e.g. cognitive scientists and IT specialists). Medicine of course will play its important role here because an implantation of such a novel invention must be carried out in the clinical setting and requires strictly medical resources. In this way, there will be bioethical aspects of applications of those implants but an issue if they should be produces at all will lie beyond medicine and bioethics as such. A probable rationale for their manufacturing will have to do with convictions that things should be produced when they can be produced, according to the technological imperative ("if something is technically possible, it is morally allowably and even obligatory”).

Application of artificial things replacing natural ones is traditionally considered in transplantation ethics. However, such procedures are morally allowable when natural organs or tissues are unviable (not working well) through illness or accident and there is no ready donor (living or dead); or it is better to apply artificial elements like an artificial hip or heart valve because of their parameters. Thus, an underlying assumption is that replacements have a therapeutic character aimed at restoration of health. That is not the case when transhumanists set out their proposals. Their thinking concerns radical enhancements, which go well beyond the logic of traditional treatment (understood in Hippocratic medicine). The aim is not to restore people's health but to change their condition first into a transhuman creature and finally into a posthuman one. Of course, at present no one is able to describe precisely those extra-human conditions. Transhumanists themselves limit their efforts to a quite sketchy and general 
characterization. As Nicholas Agar claims, transhumanists describe that post-human condition in a very selective way concentrating only on desired characteristics (Agar calls that "focalism") (AGAR, 2010, p. 145ff).

All in all, the engagement of bioethics in the transhumanist project will be partial. The issues like production of artificial organs, the aim of their implantation seem to go beyond bioethics and touch more on the ethics of technology and the ethics of future generations, etc.

\section{Bioethics as Transhumanism}

It is very intriguing that many philosophers who were involved in bioethical debates in recent years took a great interest in transhumanism. For example John Harris or Allen Buchanan who were so much involved in typically bioethical issues like patient autonomy, abortion or stem cell ethics, have switched into a realm of transhumanist considerations by publishing leading books in this area (see e.g. HARRIS, 1985; BUCHANAN, BROCK, DANIELS, and WIKLER, 2000). It can be understood in two ways. First, a traditional bioethics has exhausted its potential and the "remnants of bioethics" have been transferred to the realm of law and politics. In other words, theoretical debates have shed enough light on those traditional bioethical issues and now it is a high time for decisions, including political decisions, and corresponding law regulations. There are of course some premises proving that this is indeed the case, especially in the English-speaking world (who is today a bioethicist in the US?). However, this interpretation is superficial and does not explain well the change of the orientation of world known bioethicists. Thus, second, transhumanism offers a new outlet for bioethical debates - a kind of a new framework for them.

Transhumanism has more to do with bioethics than it seems at first glance. There are some plains on which we can consider this vicinity. First, adherents of transhumanism are interested in almost all issues constituting the realm of the contemporary bioethics. To give only a few examples, they entertain a vivid interest in the beginning of human life because they are aware that any genetic long-lasting interventions can be performed only at this stage. They are also interested in transplantations because only within this set of procedures novel and more efficient transplants can be implanted. Transhumanists are 
very concerned with the end of human life too because its overcoming is one of their main aims. In general, transhumanism without hard sciences, including biomedical ones, is doomed to remain a part of futurology and even science fiction. Consequently, what has been worked out by bioethical investigations must belong to a set of transhumanist endeavours if they are to be treated seriously.

However, transhumanism is even more associated with bioethics in its very foundations. This association we would call: the care for the buman wellbeing. Bioethics is generally concerned with ethical dimensions of various undertakings applied to the human being. There is here a strong conviction that mere technical assessment is not sufficient; that the human body, for example, cannot be treated as a bio-machine where technical expertize determines how we should treat it. The human being is not only a bodily creature but exists also on the extra-empirical level, where such categories as spiritual and interpersonal life, the good, the moral duty, and the like are important. All bioethical discussions are underpinned by a conviction that we cannot allow for immoral solutions because they work, sooner or later, against the human being himself. Thus adequately recognizing and respecting the moral order is important for the human wellbeing. In a sense, there is present here the Aristotelian thesis that morality is an essential part of human happiness and fulfilment. Of course, various bioethicists draw on various ethical systems, which sometimes are at odds with each other. Usually a bone of contention is a fundamental understanding of morality; as the illustrious example, we can point to a difference between the personalistic ethics and utilitarian one: Morality as a way of maximising a broadly understood profit or morality a promotion of personhood and its dignity.

Transhumanism is also concerned with wellbeing of posthuman creatures. Those creatures — according to a standard transhumanist belief — will be created out of human beings after a massive implementation of enhancing procedures ${ }^{2}$. Moreover, the sole transhuman and later posthuman individual must embody a better state of existence and

\footnotetext{
${ }^{2}$ Allen Buchanan gives several examples of such procedures. They include "(1) selection of embryos for implantation according to genotype (if genotypes associated with "better than normal" phenotypes could be reliably identified); (2) genetic engineering of embryos, by insertion of human or nonhuman animal genes or artificial chromosomes; (3) administration of drugs (e.g. cognitive enhancement drugs); (4) implantation of genetically engineered tissue or organ; and (5) brain-computer interface technologies, using nanotechnology to connect neural tissue with electronic circuits" (BUCHANAN, 2011, p. 25).
} 
thus - to be a first step in the process of improving of human existence (just to "relieve" the human state). As we have mentioned above, this transformation into a transhuman and posthuman condition will be connected with abandonment of the sphere of biology because, as it is believed, we can replace biology with something better. It means primarily that those functions (higher functions typical for the human being) can be recreated on stronger, more resistant grounds than biological one.

If transhumanist attempts in replacing human biology were successful, then it would prove that the human being can be transferred onto a completely new ground or a new vessel. Consequently a consideration on his biological condition, including bio-ethics, would be replaced by a consideration concerned with his new underlining nature; the nature primarily created by interventions typical for IT and nanotechnology, to give a few examples. The new-embodied creature will require such a reflection, including an ethical reflection, because its functioning will be still associated with a kind of wellbeing. Of course, nowadays no one is able to foresee what precisely that wellbeing will be all about.

The attempt to transfer the human life into a completely new sphere would have to do with a progressive fusion with the world of machines; at the end of this process there will be no difference between a posthuman and a machine ("machines didn't replace us, we ourselves have become them"). The body will be replaced by a kind of very advanced machine and the so-called biological intelligence will merge with machine intelligence. Such a prediction is voiced at present by some adherents of artificial intelligence, like for example by the founder of Tesla - Elon Musk. As to the ethics itself, bioethics will be turned into cyborg ethics, transhuman ethics and finally posthuman ethics. This passage could be achieved suddenly but more likely it will be a result of a smooth transition over a longer period of time. A progressive implementation of artificial elements into a human body will require a gradual change in the ethical considerations. What could be said about a character of this new ethics?

\section{Ethics of Transhumanism}

Actually, it is not so easy to answer this question. From the start, we find quite serious obstacles to characterizing the ethics of the future. First, we have only some 
premises to determine that approaching and projected future; many expectations, especially those entertained by transhumanists, seem to be very distant and unrealistic. For example, we do not know if the progress in exact sciences and corresponding technologies will enable us to produce such highly sophisticated organs like the artificial cortex. Second, we do not know who or what a transhuman and even more posthuman creature will be $\mathrm{be}^{3}$. It is extremely difficult to foresee a condition of that creature and some philosophers claim that there will be not such a condition but the constant flow of changes. For example, Nicholas Agar argues that the basic logic of transhumanism is about change and not about achieving a relatively stable state of existence. Thus, a change just implemented will be, in a moment, challenged and overcome in order to introduce a further enhancement (AGAR, 2014, p. 77). This change will be something more than an expression of the dynamics of the entity: it will probably not stem from within (from a set of processes) but will be imposed from without (prompted by a mind of that posthuman creature or by a decision of the posthuman society). Because of these difficulties, the ethics of the transhumanist world is difficult to foresee: when the drive for radical enhancement governs, all other issues including ethical ones are secondary.

However, we can attempt to predict some features of that ethics based on what transhumanists declare right now. It seems that it will absorb the ethics/bioethics, which is typical for the contemporary stage of debates and later - it will mutate it into a kind of new ethics. The first step will be about assuming many achievements of the contemporary bioethics but because of implementation of radical changes into a structure of the human being, it will go further. Thus, a new ethics will get a shape, which is clearly different to contemporary bioethics. As we have mentioned already, it is quite hard to foresee an exact shape of that new ethics. However, there are some premises allowing us to say something about it. Something which seems to be obvious is a shift from the concentration on bio-sphere into the concentration on techno-sphere. This move will be gradual, taking into account the logic of departing of the human world. Replacing one organ after another will lead to a situation that the human being is partly natural and partly artificial. This is a reality, which is usually described as a being a cyborg, as

\footnotetext{
3 This difficulty is quite often voiced by critical analysts and observers of transhumanism (see e.g. AGAR, 2012, p. 144-145).
} 
mentioned above. Imagine, however, a continuation of this move up to the point that the human being ceases to be human and his functions, although of human origin, are performed in a new way, namely they transgress even what a typical of an outstanding human being is able to. Thus, ethical reflection will be a result of that change and consequently, a human-centred ethics will be turned into a post-human-centred ethics.

This scenario is burdened with many difficulties, both theoretical and practical. Some of them have been mentioned already. However, the main problem consists in a dilemma whether we can transfer the humanity from the realm of bio into the realm of techno. Some thinkers are convinced that it is possible; they, like Ray Kurzweil, suggest that humanity is basically about our mental and personality-related features and it can be inserted on whatever appropriate ground, or vessel: like software downloaded to a new hardware (as a part of the uploading of the person). Opponents of this fundamental thesis claim that to be a human is to be a bodily creature, where biology plays its vital role. Transhumanist as such consider biology as a limitation and the techno-sphere is for them more promising. Thus, the ethics of transhumanism will be not a bio-ethics but a techno-ethics, where ethical considerations on biology-related processes as well as the ethics of life associated with biology will be put aside and finally relegated to the realm of natural history.

In such a project, the life will be identified with empirical phenomena and technical functioning. Ethical investigations will be concerned primarily with implementation of new artificial parts; and the criteria will be about whether those new elements increase the power of a given operation and what kinds of side-effects they bring about. This ethics will have to do more with an imagination of a posthuman creature than with respecting its current condition (a current condition always will be something to overcome). Moreover, the condition will be something what is created rather than discovered. Thus, transhumanist ethics will be always orientated toward the future where the imagination will be a main leading force. In contrast to this scenario, we must say that the contemporary bioethics deals all the time with novel interventions (therapies, drugs, etc.) but is also concerned with an inborn condition of the human being, including his biological sphere. The ethics of transhumanism will be concerned with what a posthuman entity can become but in a clear opposition to its biological past and present state. 


\section{Bioethics in the Grip of Transhumanism?}

Is bioethics endangered by the ethics of transhumanism? If bioethicists accept transhumanism as a new face of bioethics, without any reservations, such a scenario can indeed take place. However, there is no such a necessity and we can consider a less radical version. One thing seems certain: bioethics must meet transhumanism and answer some dilemmas generated by the latter. Let us point out to one necessity: bioethical discussions cannot put aside the whole area of human enhancement because this activity is already taking place. For example, vaccines and some drugs used within preventive medicine endow on the human organism qualities, which the latter does not possess in the natural course of things; they modify our biological nature. Thus, in bioethical debates we cannot avoid considering them and determining to what extent they are morally permissible. However, bioethics as such should distance itself from a radical enhancement, which is a core of transhumanist speculations. Bioethics should stick, with its analyses, to a therapeutic enhancement and at most — to a moderate one. That means that thinking in terms of becoming an extra-human creature is beyond what is typical for bioethics. This area of ethical analysis and discernment is about a present condition of the human being, which can be improved, upgraded but not overcome. Bioethics is not about the limitlessness of the human being; rather human limits are hallmarks of its analyses.

\section{Conclusions}

A number of famous bioethicists who move to the field of transhumanism do not mean that there is a necessary link between these two areas. They are relatively separate and can operate as such. Bioethics is conducted within a realistic worldview and should keep a clear distance to a kind of idealistic worldview present in transhumanism. It means that in the centre of bioethics is the human reality, which we discover and deal with right now, whereas in the centre of attention of transhumanism is the projection of whom the human being can become in the future. An important role is played, in the latter, by the tendency to increase happiness. However, as medicine is not about bringing about an increasing state of happiness of the human being, thus bioethics is not about calculations 
how to achieve it and how moral or immoral it is. Thus, despite a tendency to redefine bioethics within a new transhumanist paradigm, it is the autonomous area of ethical considerations and needs not to be considered as a part of futuristic and science-fictionlike speculations.

\section{References}

AGAR, N. Humanity's End. Why We Should Reject Radical Enhancement. Cambridge/London: The MIT Press, 2010.

AGAR, N. Why we can't really say what post-human persons are? Journal of Medical Ethics, v. 38, n. 3, p. 144-145, 2012.

AGAR, N. Truly Human Enhancement. A Philosophical Defence of Limits. Cambridge (MA)/London: The MIT Press, 2014.

BOSTROM, N. A History of Transhumanist Thought. Journal of Evolution \& Technology, v. 14, p. $1-21,2005$.

BUCHANAN, A. Beyond Humanity? The Ethics of Biomedical Enhancement. New York: Oxford University Press, 2011.

BUCHANAN, A.; BROCK, D. W.; DANIELS, N.; WIKLER, D. From Chance to Choice. Genetics and Justice. Cambridge: Cambridge University Press, 2001.

CALLAHAN, D. Bioethics. In: Encyclopedia of Bioethics. v. I (ed. Steven. G. Post). New York: Thomson \& Gale, p. 278-287, 2004.

HARRIS, J. The Value of Life. An Introduction to Medical Ethics. London/New York: Routledge, 2005.

KURZWEIL, R. The Singularity Is Near: When Humans Transcend Biology. London: Penguin Books, 2005.

TRANSHUMANIST DECLARATION. In The Transhumanist Reader. (eds. Max More, Natasha Vita-More). Oxford/Malden: Wiley-Blackwell, p. 54-55, 2012/2013. 